\title{
UNDERSTANDING EMPLOYEES' INTRAPRENEURIAL BEHAVIOR: A CASE STUDY
}

\author{
Georgiana-Alexandra Badoiu, Mercedes Segarra-Ciprés and \\ Ana B. Escrig-Tena \\ Department of Business Administration and Marketing \\ Universitat Jaume I, Castellón, Spain
}

\begin{abstract}
Summary
Purpose - The purpose of this study is to provide a deeper insight into the organizational factors and personal motivations of intrapreneurs which may foster intrapreneurial behaviors of employees in a new technology-based firm (NTBF).
\end{abstract}

Design/methodology/approach - The paper takes a qualitative approach to exploring organizational and individual antecedents of employees' intrapreneurial behavior. A single case study was conducted based on semi-structured interviews with the founders and top managers of the firm and with intrapreneurial employees.

Findings - Results show that intrapreneurial projects may arise in firms whose top managers support Corporate Entrepreneurship (CE) in a non-active manner. Intrapreneurial behaviors of employees can emerge despite the lack of time and limited resources available for undertaking projects. Moreover, work discretion and mutual confidence and the quality of the relationship between employees and top managers are the most valued factors for intrapreneurs.

Practical implications - Based on the intrapreneurial projects studied, this paper helps to contextualize intrapreneurs' perception of organizational support and the personal motivations for leading projects within an NTBF.

Originality/value - Traditionally, the literature has mainly focused on the top-down implementation of entrepreneurial projects within large firms. This paper contributes to the understanding of the combination of firm- and individual-level factors that facilitate intrapreneurial behaviors of employees. It also illustrates the contextual conditions and the firms' orientation on CE within an NTBF.

Keywords: intrapreneurship, organizational support, motivations, new technology-based firm (NTBF)

\section{Introduction}

Firm-level entrepreneurship, or Corporate Entrepreneurship (CE), refers to entrepreneurial activities within existing firms, such as venturing, innovation, and strategic renewal (Burgers and Covin, 2016). Interest in how CE can be enhanced within established companies (Corbett et al., 2013) and the amount of research being conducted on this topic are both growing due to the potential to renew companies through innovative initiatives. According to Antoncic and Hisrich (2001:504) "organizations that engage in intrapreneurial activities are expected to achieve higher levels of growth and profitability than 
organizations that do not". Moreover, Gerasymenko et al. (2015) point out that CE can renew a company's capabilities and increase its capacity to acquire and use new competencies that improve performance.

Entrepreneurial activities within organizations can be developed at every level (Monsen and Boss, 2009; Wales et al., 2011). Research on CE at the individual level refers to intrapreneurs, that is, employees who have the ability to turn ideas into business success or to develop innovations (Pinchot, 1987; Moriano et al., 2014). Specifically, one line of research on CE has focused on the conditions that motivate individuals to behave entrepreneurially given a particular organizational context (e.g. Arz, 2017). Regarding those conditions, some authors (e.g. Dess et al., 2003; Rigtering and Weitzel, 2013) highlight the need to study the organizational factors that facilitate intrapreneurship. A valuable quality of corporate entrepreneurship is the creation of an environment that stimulates entrepreneurial thinking and behavior (Antoncic and Hisrich, 2001). In this respect, Ireland et al. (2006) state that the CE Assessment Instrument (CEAI) can be a useful and effective tool that managers can use to supervise and enhance CE activities. This instrument captures five organizational factors that help promote intrapreneurial behavior, namely, management support for entrepreneurship, work discretion, rewards, time availability, and organizational boundaries (Hornsby et al., 2002; Kuratko et al., 2014). Consistent with these arguments, our first objective is to examine the dimensions of the CEAI that may support employees' engagement in intrapreneurial behaviors.

In addition to work environment conditions, individual factors may also help to capture the intrapreneurial behavior of employees. Thus, Stull and Singh (2005) indicate the need to understand why some employees within an organization develop intrapreneurial behavior while others do not, despite being exposed to the same organizational context. Some authors emphasize the importance of considering aspects associated with the intrapreneurs' personality and their chances of promotion in the company as factors that can also explain the initiative to establish projects led by employees. Particularly, Carrier (1996) points out a series of motivating factors associated with the personality and experience of employees which can be the driving force on which intrapreneurial initiatives are based. Thus, our second objective is to explore the main factors that motivate employees to undertake intrapreneurial projects.

Research on the specific conditions under which internal entrepreneurial initiatives of firms can prosper, in particular types of organizations, is also scarce (Rigtering and Weitzel, 2013), and a recent stream of research even shows that different intrapreneurial conditions may explain employees' intrapreneurial behavior in SMEs and in large firms (e.g. Zellweger and Sieger, 2012; Hughes and Mustafa, 2017). Analysis of the conditions that may promote CE in a specific subgroup of SMEs, NTBFs, is paramount, since these firms normally operate in sectors that are both dynamic and fraught with uncertainty (Wang, 2008), where a constant search for new opportunities, innovation, and strategic flexibility are crucial to address environmental pressures (Hughes and Mustafa, 2017). In addition, NTBFs generally suffer from resource constraints and, as a result, need to closely integrate 
entrepreneurial and market orientations into their business strategy in order to improve performance (Buli, 2017).

In view of the above considerations, the purpose of this study is twofold: (1) to determine the internal organizational factors that go together with the development of intrapreneurial behavior by employees, and (2) to discover the motivations driving intrapreneurs to propose and lead projects within the company in the context of an NTBF. The contribution of this study is threefold: 1) Most studies in the field of intrapreneurship research are based on the consideration of environmental and organizational antecedents of intrapreneurial activity. However, there is scarce evidence of the combination of contextual and personal factors as drivers of intrapreneurial behaviors of employees. In this vein, we discuss the combination of these factors that could explain the high levels of intrapreneurial behavior through an in-depth analysis of the facilitators of intrapreneurship in four intrapreneurial projects. 2) Analysis of the conditions that may foster employees' intrapreneurial behaviors in the context of an NTBF is scarce. The selection of this kind of firms is paramount in the study of intrapreneurship phenomena because they operate in technological and dynamic sectors that are oriented to the continuous search for opportunities for developing technology-based products and services (Saemundsson and Candi, 2017). Studying intrapreneurship in this context is interesting since, as suggested by Hornsby et al. (1993), this kind of environment may precipitate intrapreneurial activity when other conditions such as organizational and individual characteristics are conducive to such activity. 3) While other case studies focus only on managers' perceptions (e.g. Sebora et al., 2010), this paper presents a case study that allows analysis of intrapreneurship facilitators from the perspective of intrapreneurial employees and top managers, thereby providing a more accurate perspective of intrapreneurship activity.

The remainder of the paper is structured as follows. First, we present the theoretical framework to analyze the organizational and personal antecedents of employees' intrapreneurial behaviors. Then, through a qualitative analysis based on a case study where successful intrapreneurial initiatives from employees were developed, we offer a more in-depth understanding of the antecedents of intrapreneurial initiatives within the context of an NTBF. The case study is based on four intrapreneurial projects from a leading firm in the information technology sector. A benchmark in the local entrepreneurial ecosystem, in only five years, this firm has experienced exponential growth after commencing its international trajectory in seven countries. The paper closes with a discussion of the findings, main conclusions, and limitations.

\section{Conceptual framework}

\section{Intrapreneurial behavior of employees}

The term 'intrapreneur' refers to an employee who combines ideas and uses existing resources in the organization to promote innovative new projects (Pinchot, 1985). Intrapreneurs share many 
characteristics with entrepreneurs, the main difference being that the former decide not to leave their organization or risk their capital in order to carry out their ideas independently, but instead use the resources of the organization to innovate and promote change. Intrapreneurial behavior is defined by three aspects (Covin and Slevin, 1989; Rauch et al., 2009; Rigtering and Weitzel, 2013), namely, a set of innovative, proactive, and risk-taking behaviors. Employees who engage in intrapreneurial behaviors foresee or prompt change, and proactive employees are frequently considered by organizations as drivers of innovation (Grant and Ashford, 2008). This is suggested by authors such as Rauch et al. (2009), who show how intrapreneurial behavior improves the results of companies, especially those that operate in dynamic and turbulent environments (Covin and Slevin, 1989; Wiklund and Shepherd, 2005; Kraus et al., 2012). In this regard, Hornsby et al. (1992) highlight the relevance of firms recognizing these behaviors among their employees and matching them with the particular entrepreneurial needs of the organization. Moriano et al. (2009) suggest that employees' intrapreneurial behaviors allow the organization to renew itself from within and thus improve its competitiveness in the market.

\section{New technology-based firms (NTBFs)}

The concept of NTBF has been used in both a narrow and a broad sense (Storey and Tether, 1998). Little (1977) refers to NTBFs as firms that are less than 25 years old and focus their attention on exploiting technological innovations. A broader definition includes all new firms operating in high technology sectors (Shearman and Burrell, 1988). Most definitions emphasize the recent creation of the firm, their orientation toward the development and commercialization of new technological products or services, and the presence of specialized personnel with technical expertise (e.g. Bollinger et al., 1983; Storey and Tether, 1998; Bruneel et al., 2017; Saemundsson and Candi, 2017). In this study, we refer to NTBFs as new firms focused on the development of technology-based products and services.

\section{Antecedents of intrapreneurship}

Entrepreneurship literature distinguishes two main types of internal antecedents to explain the entrepreneurial action on which $\mathrm{CE}$ is built. On the one hand, the literature highlights the antecedents from the organizational contexts in which employees operate (e.g. Hornsby et al., 2013; Croneen et al., 2016). Assessing the state of organizational preparedness for CE represents an important element for successfully implementing a CE strategy and stimulating entrepreneurial behaviors. In this vein, CEAI condenses different internal organizational factors referring to managerial support, incentive systems, organizational structure, and culture (Hornsby et al., 2013; Kuratko et al., 2014; Hughes and Mustafa, 2017). On the other hand, another CE stream is based on the personal factors of intrapreneurs such as individual entrepreneurial cognitions (e.g. Ireland et al., 2009) or motivational factors (e.g. Carrier, 1996; Kuratko et al., 2005; De Clercq et al., 2011) as core antecedents of entrepreneurial efforts within firms. The interactionist perspective (Woodman et al., 1993; Oldham and Cummings, 1996) suggests that the basis for understanding the influence of employees' behaviors on the organization is the 
interaction between personal factors of employees and the organizational context. In this sense, the interactive model of CE (Hornsby et al., 1993) is based on the combination of individual and contextual factors of firms as antecedents of firms' entrepreneurial activity. Following this model, we explore the contribution of both types of factors toward understanding the intrapreneurial activity of employees.

\section{Organizational support for the intrapreneurial behavior of employees}

Intrapreneurial behavior is not a stable feature of the individual, but includes a situational component, determined by organizational variables and the job position (Rigtering and Weitzel, 2013; Moriano et al., 2014). Hence, the entrepreneurial orientation of the company and, particularly, the company's support for the initiatives proposed by its employees can promote the intrapreneurial behavior of employees insofar as they influence their motivation to initiate projects within the company. Some authors (e.g. Hornsby et al., 2002; Kuratko et al., 2014) highlight the analysis of organizational antecedents in the development of intrapreneurial activities within firms. In line with these authors, the Corporate Entrepreneurship Assessment Instrument (CEAI) provides a means to assess, evaluate, and manage the firm's internal work environment in ways that are conducive to entrepreneurial behavior (Kuratko et al., 2014). The CEAI includes five dimensions: top management support, work discretion, rewards and reinforcement, time availability, and organizational boundaries.

(1) Top management support refers to the degree to which entrepreneurial behavior is encouraged, assisted, and endorsed by top-level management, which includes defending innovative ideas and ensuring that the resources needed by employees to undertake entrepreneurial actions are made available. Thus, Lukes and Stephan (2017) emphasize the role of managerial support as an antecedent of employees' innovative behavior. In the case of small firms, some authors (e.g. Hughes and Mustafa, 2017) stress that managers should pay attention to the importance of more informal mechanisms by encouraging interactions among employees.

(2) Work discretion encompasses the extent to which the organization tolerates failure, allows for a certain amount of scope in decision-making while also ensuring supervision is kept to a reasonable level, and entrusts lower-level managers and workers with greater authority and responsibility. Most studies claim that in many cases those in the best position to identify opportunities for entrepreneurial behavior are those responsible for judging how work should be carried out, and those who are encouraged to experiment. In this regard, Hornsby et al. (2002) state that entrepreneurial outcomes are achieved when employees have freedom, enjoy some level of responsibility, and failure is not excessively penalized.

(3) Rewards and reinforcement comprise the extent to which the organization implements schemes to offer its workers rewards in recognition of entrepreneurial undertakings and success. There is evidence 
to show that the characteristics of varying reward systems could influence individuals' conceptualization of benefits (Carraher et al., 2003), encourage them to take risks and innovate, and also have a powerful influence on their tendencies to behave in entrepreneurial ways. Specifically, if an individual is rewarded for displaying entrepreneurial behavior, he or she is more likely to engage in innovative, proactive, and moderate risk-taking behavior (Monsen et al., 2010).

(4) Time availability refers to individuals and groups being given extra time to work on innovations. This is achieved by organizing their workload in such a way as to allow them time they can devote to such endeavors with the aim of reaching short- and long-term organizational goals. Allowing corporate innovators a certain amount of time that is not previously scheduled for the work at hand enables them to seize opportunities for innovation that they may not have time to consider during the time stipulated for their regular work activity. Hornsby et al. (2002) note that individuals need time to foster new and innovative ideas. However, employees' workload needs to be arranged in such a way as to allow them enough time to work on long-term problem solving (Sebora et al., 2010).

(5) Organizational boundaries refer to the development of processes that reduce uncertainty in the performance of tasks so that employees can perceive that processes do not prevent the development of new ideas. According to Kuratko et al. (2014), these boundaries can be achieved by providing explanations of outcomes expected from organizational work and by developing mechanisms for evaluating, selecting, and using innovations. Thus, innovative results emerge in a more predictable way when innovation is considered as a structured process.

\section{Personal motivations of intrapreneurs}

Intrapreneurs have the ability to accept and overcome challenges (Cox and Jennings, 1995), and their entrepreneurial orientation allows them to reduce exhaustion from demanding working conditions (Kattenbach and Fietze, 2018). They are intrinsically motivated by the interest, enjoyment, and sense of achievement of their work, and look for new opportunities, ideas, and improvements (Cox and Jennings, 1995; Smith et al., 2016). Personal motivation for intrapreneurs is "largely dependent on individual personality, characteristics, and personal situation, and includes factors related to temperament, past experience and personal career objectives, and existing or future rewards that have value" (Carrier, 1996: 12). According to Mohanty (2006), when intrapreneurs are motivated to take action, intrapreneurship is successful. Therefore, it is important to understand the personal motivational factors that drive intrapreneurs to engage in intrapreneurial projects.

Carrier (1996) distinguishes four groups of personal motivations for intrapreneurs. The first of these, "intrinsic personality-related motivations", refers to autonomy and freedom in the development of one's work. The second group, "extrinsic, reward-related motivations", refers to satisfaction with the characteristics of the job itself, and includes, for example, promotion, access to capital stock, or a higher 
salary than could be obtained elsewhere. The third group includes motivations related to past experience and future career goals, such as the desire to work for oneself, past experience as an entrepreneur, past experience as an intrapreneur, the attraction of going back into business in one's "native village", and being "plateaued" (in the restricted sense) in a previous job. Finally, motivations related to the organizational context refer to a management style that welcomes intrapreneurship, a sense of belonging, a shared vision with the entrepreneur and mutual confidence, and the quality of the relationship.

Based on the interactive model of CE (Hornsby et al. 1993), we propose taking internal organizational factors and personal motivators of the intrapreneur into consideration as antecedents of the intrapreneurial behavior of employees. Thus, we explore the following research questions:

$R Q 1$. What dimensions of the CEAI are perceived by intrapreneurs when they develop intrapreneurial projects in new technology-based firms?

RQ2. What kind of personal motivations encourage intrapreneurs to propose and lead an intrapreneurial project within the firm?

\section{Methodology}

Previous studies (e.g. Zahra and Wright, 2011; Hughes and Mustafa, 2017) highlight the need for qualitative research to explore the organizational antecedents of entrepreneurial behavior in firms. We conducted an exploratory study using a case-study approach (Bowen, 2008; Yin, 2009) in order to explore the research questions proposed. Case study research is gaining popularity among qualitative researchers (Thomas, 2011). According to Yin (2009), a case study allows any phenomenon to be understood in its real-life context and is based on multiple sources of evidence. Moreover, case studies are helpful for generating theory and analyzing the "how" and "why" (Eisenhardt and Graebner, 2007; Yin, 2009). In this study, we explore "how" an organization fosters intrapreneurial behaviors in its employees and "why" the employees engage in intrapreneurial projects, based on our qualitative analyses.

\section{Case study - Soluciones Cuatroochenta}

The company selected for the case study is Soluciones Cuatroochenta, a new technology-based firm operating in the information and communication technology sector and specializing in the development of mobile applications and digital transformation. Soluciones Cuatroochenta has its headquarters in Castellón de la Plana (province of Castellón, Spain) within the Science, Technology, and Business Park of the Universitat Jaume I (UJI), which specializes in fostering innovation. Soluciones Cuatroochenta was founded in 2011 and from the outset its strategic focus was on growth. In only five years the 
company had already spread to seven countries: Spain, Panama, Columbia, Argentina, the United States, Italy, and the Netherlands. The number of employees also grew quickly to meet increasing demand and by 2017 it had 37 employees. Nowadays, Soluciones Cuatroochenta is a benchmark company in Spain. In 2015, it received an award for its entrepreneurial trajectory from the Network of European Centers of Innovative Companies (CEEIs) of the Valencian Community and the Valencian Institute of Business Competitiveness (IVACE). In addition, in 2014, Forbes magazine stated that Soluciones Cuatroochenta is "one of the most innovative companies in Central America", thanks to various projects carried out in Panama. We selected Soluciones Cuatroochenta for our investigation because it has developed relevant intrapreneurial projects, which demonstrate a variety of specific CErelated initiatives as evidence of the intrapreneurial behavior of employees (see Table 1 for the specific projects). Hence, we have approached the intrapreneurial behavior of employees by taking into account the projects deriving from their intrapreneurial activity.

We present four intrapreneurial projects from Soluciones Cuatroochenta developed by four employees. We used fictitious names (Alpha, Beta, Gamma, and Delta) for each project to ensure confidentiality. Intrapreneurial behavior can generate many different forms of well-defined innovations (result achieved) in the small business context. New products, services, processes, areas, or business developments are some of the outcomes of the intrapreneurial process (Carrier, 1996; De VilliersScheepers, 2011). In the case presented here, the results achieved refer to two new ventures (Alpha and Gamma), a new service (Beta), and a new area (Delta). In order to analyze intrapreneurship in the company, we also used secondary sources such as the company's official website, its blog and social media accounts, as well as access to other websites to collect more information. In order to better understand the intrapreneurial projects studied, following Carrier (1996), Table 1 summarizes the main features of each project.

\section{[TABLE 1]}

Alpha. This is a new company resulting from an intrapreneurial process. A member of the app development team at Soluciones Cuatroochenta, together with two other colleagues, developed this application, which allows users around the world to ask for help with different skills or tasks by encouraging collaboration. Spain is in the top five EU countries with the highest potential for growth in the collaborative economy, and Alpha detected a need poorly covered by the solutions on offer: how to exploit and monetize abilities, while helping others and getting extra income. Consequently, the project was created as a collaborative economy platform. The differential factor of Alpha is its ease of use, free service and, above all, its speed, agility, and efficiency.

Beta. This all started when an employee saw the potential of an interactive tool developed for a client to become a powerful tool used as an additional product of Soluciones Cuatroochenta. The intrapreneur was in charge of starting this project and received support from the organization and a team to help in different business areas. Beta is now a software application that enables InDesign documents 
to be converted into interactive applications for iPad and Android tablets that can be distributed worldwide through App Store and Google Play.

Gamma. This project was born as a response to a demand: the need to convert the ideas generated in the surrounding environment into real business, while simultaneously injecting them with all the variables needed to maximize their value and successfully compete in the professional arena. Gamma is a new venture, based on a platform for boosting technological projects that focuses on closely monitoring each project in which it is involved. The number of projects being driven is very limited and it participates at every step of the project from the earliest stage.

Delta. The result of this project is a new department created by the firm and totally different from its main activity. This is a clear case of innovation in which an employee manages the project.

\section{Data collection}

Data collection took place from January until May 2017. We developed a qualitative study based on interviews and questionnaires as primary sources of information. Each interview lasted between 20 and 40 minutes and followed a standard protocol, with questions designed to elicit information about two different aspects: whether the company offers organizational support allowing employees to carry out the different projects presented (in relation to RQ1); and the motivations of intrapreneurs (RQ2). The answers given in the interview were recorded and later transcribed.

Two different kinds of informants were approached. First, the two founder-managers (CEO and CTO) of Soluciones Cuatroochenta answered questions about the dimensions of the CEAI. Second, the promoters of four intrapreneurial projects within the company reported on issues concerning personal motivations to engage in a project and the evaluation of the dimensions of the CEAI. Two questionnaires were designed. The first was sent to both managers and to the promoters of the projects, in order to evaluate the support offered by the company for internal initiatives. The questionnaire was based on a literature review, hence the instruments used to measure the different constructs were taken from validated scales.

In order to analyze the effective support given to intrapreneurial projects, the CEAI was used following Hornsby et al. (2002), who refer to five dimensions, each composed of their respective items: management support for entrepreneurship (19 items), work discretion (10 items), reward/reinforcement (6 items), availability of time (6 items), and organizational boundaries (7 items), totaling 48 questions. Participants responded to the items of the CEAI using a five-point Likert-type scale, with 1 representing "Totally disagree" and 5 representing "Totally agree" regarding the perception of their workplace and organization. Because the instrument was developed according to a well-grounded theory (Kuratko et al., 1990; Hornsby et al., 1999; Hornsby et al., 2002), we can rely on its content validity. Moreover, Kuratko et al. (2014) concluded that CEAI is recognized as a reliable and valid scale to measure the dimensions of the organizational environment that may trigger intrapreneurial behavior. It has been 
used extensively in the corporate entrepreneurship literature, and other scholars have also drawn conclusions on its reliability, and convergent and discriminant validity in the context of their own research (e.g. Moriano et al., 2009; Sebora et al., 2010; Urban, 2017). In addition to survey research, this instrument has also been used to conduct interviews in previous case studies on antecedents of corporate entrepreneurship (e.g. Sebora et al., 2010; Hughes and Mustafa, 2017).

The second questionnaire was sent only to the intrapreneur in order to analyze the personal motivating factors of employees leading the intrapreneurial projects studied. To assess their motivating factors, we used the scale developed by Carrier (1996), distinguishing between intrinsic personality motivations (5 items), extrinsic reward-related motivations (5 items), motivations related to past experience and future career goals (5 items), and motivations related to the organizational context (4 items). The intrapreneurs were required to order the factors (items) proposed by Carrier (1996) from a lower to a higher level of importance, or even to add another new factor that was not listed.

\section{Results}

Regarding the first research question, we first present the vision of the firm's two founders on corporate entrepreneurship and the organizational support given to employee-led initiatives. Both founders are also top managers in the firm. One of the founders, and CTO, considers that the firm is open to new ideas from its employees, although it has no active position on this. In particular, he stated:

"You do not have to do a job of activating people to be intrapreneurs, since there are people who do not have the profile to be an intrapreneur and the company should not force it. If it arises, we will support it, as, for example in the case of Beta. It is more a reactive than an active process, since there are many people within Soluciones Cuatroochenta's team who do not have an intrapreneurial profile but are great at doing what they do. Intrapreneurs will arise and when they do, we will support them, but we do not believe that it is necessary to make an active effort to do so".

This view is in line with Hisrich and Kearney (2012), who believe that top management should motivate the intrapreneurs in their organization but avoid imposing entrepreneurial thinking on them. The CTO is also aware that the intrapreneurs in the company have both technical (engineers) and business (marketing) profiles. This proves that engineers can be key drivers of technological innovation and new venture creation (Fayolle et al., 2005), but they are not the only ones. Employees with a less technical profile, but more versed in marketing, for example, can also be key drivers and leaders of intrapreneurship.

The other founder, and CEO of Soluciones Cuatroochenta, believes that corporate entrepreneurship has its advantages and disadvantages. As for the negative side, this founder points out that corporate entrepreneurship is demanding in terms of control, stating: 
"No direct control because it would limit the intrapreneurship too much, but indirect control, since you have to exercise more control over the variables of the company, its resources. The company has limited resources, and this requires a lot of coordination among the parties involved."

As an advantage of CE, firms gain in flexibility, which would have its advantages over a rigid structure. The same respondent remarked:

"But if intrapreneurs had to receive clearer guidelines and procedures to develop intrapreneurship, they would lose flexibility, which would also slow everything down because there is limited time and capacity".

This idea is in line with Dean et al. (1998), who claim that there are a number of advantages for smaller firms, such as speed, flexibility, and different capabilities allowing them to fill niches, and these differences may affect how, why, and when SMEs implement corporate ventures. In addition, the CEO explains that their business ideology is focused on the firm's growth. The CEO concludes that if you prepare everything well and are aware of the challenges, intrapreneurship has positive effects on the business, but if it is done without control, poor resource management may damage the organization.

In order to assess the influence of the dimensions of the CEAI as organizational support for employees' initiatives, we created two profiles of the founders and intrapreneurs' perceptions of the internal environment for CE (see Figure 1), similar to the study by Hughes and Mustafa (2017) about the antecedents of CE in SMEs. First, we evaluated the levels of the internal environment at the point of investigation using a five-point scale ranging from 1 (low) to 5 (high). Then, we formed three rating categories: low (rating 1-2), medium (rating 3), and high (rating 4-5). Finally, we calculated the mean value of each CEAI dimension in order to show graphically the differences between founders' and intrapreneurs' perceptions of the CEAI. In addition, Table 2 shows the specific aspects of each CEAI dimension rated the highest and lowest by the two different sets of interviewees (the founders and intrapreneurs), in order to understand their specific perceptions of the internal environment factors that may foster intrapreneurs' projects.

In general, we observed small differences between the profiles of founders and intrapreneurs. In particular, in comparison to intrapreneurs, founders have more positive perceptions of management support, rewards/reinforcements, and organizational boundaries, and a lower perception of time availability (see Figure 1). Our results indicate that the most highly valued dimension of the CEAI for both founders and intrapreneurs is work discretion, as this firm provides freedom for individuals to use their own judgment and the chance to do something that makes use of the workers' abilities. It should be pointed out that all the interviewees strongly disagree that practices such as criticism and punishment are alien to their work. Some of the aspects of work discretion most valued by intrapreneurs were the 
capacity to decide what they do in their job and to try their methods, as well as the chance to be creative (see Table 2).

\section{[FIGURE 1]}

Regarding top management support, both intrapreneurs and founders consider that top management is aware of and very receptive to ideas and suggestions. This supports Burgerman's (1983) idea that in SMES there are generally smaller organizational distances and direct involvement of top managers. Thus, if the communication from the management to the rest of the employees is adequate, this will increase the perception of new ideas or projects. However, they also highlight the lack of financial and economic resources to support new ideas and projects (see Table 2).

In relation to rewards and reinforcement, in comparison to the intrapreneurs, founders have a more positive perception of rewards (see Figure 1). In particular, intrapreneurs value the fact that the manager informs them if they are doing a great job and provides help to remove obstacles. Special recognition for work performance is lower and rewards for innovation are not implemented (see Table 2).

The least valued dimensions for founders and intrapreneurs are time availability and organizational boundaries (see Figure 1). Founders highlight the fact that there is very little time to think about wider organizational problems, whereas intrapreneurs feel that they always find time for long-term problem solving. Regarding organizational boundaries, intrapreneurs perceive that they have a clear understanding of the level of work performance expected from them, in terms of amount, quality, and timelines of output. However, intrapreneurs also perceive that supervisors do not often discuss work performance with employees. In sum, these results show that workload schedules in Soluciones Cuatroochenta do not ensure extra time for individuals and groups to pursue innovations and that organizational boundaries are not critical in promoting entrepreneurial activity for employees.

\section{[TABLE 2]}

Regarding the second research question, we analyzed the motivations that better explain the intrapreneurial behaviors of the project promoters within the company. Following Carrier (1996), in Table 3 we present the most and the least motivating factors of the intrapreneurs in the projects analyzed in Soluciones Cuatroochenta. We found full agreement among intrapreneurs as regards the idea that mutual confidence and the quality of the relationship in the company is a strong motivating factor. According to Carrier (1996), managers in small firms must build a strong relationship with intrapreneurs, to prevent them from leaving or even becoming competitors of their former employers. 
Other motivating factors are interest in discovering "better" ways of doing things, a need to control one's destiny, good work recognition, professional improvement, and promotion. Carrier (1996) also indicates that promotion is a significant reward, given the simplicity of the structure and the lower number of hierarchical levels in small firms. Conversely, the least motivating factor is an intrinsic personality factor: a sense of working for oneself first and foremost.

\section{[TABLE 3]}

\section{Discussion}

A major part of the research conducted in the field of CE continues to concentrate on the corporate level and tends to see entrepreneurial projects as being implemented in a top-down fashion within organizations. While this point of view continues to predominate in the literature today, researchers are increasingly of the opinion that further studies are needed at different organizational levels to reach a deeper understanding of the entrepreneurial processes that take place within established organizations (Covin and Lumpkin, 2011). The case study of Soluciones Cuatroochenta furthers our understanding of the organizational factors and the motivations of intrapreneurs that foster the intrapreneurial behaviors of the employees in an NTBF. We found that Soluciones Cuatroochenta, a five-year-old NTBF, supports corporate entrepreneurship in a non-active manner with the development of the intrapreneurial projects presented in this study. Although no procedures are implemented to increase intrapreneurship in the company, when it does arise, the founders and top managers help intrapreneurs as much as possible. Both top managers and intrapreneurs recognize the benefits associated with an NTBF, as the firm is flexible, less structured, less hierarchical, and more open to innovation and change. However, it has fewer economic resources and less time available for developing corporate entrepreneurship, since the company's business ideology is focused on growth.

Our results also indicate that intrapreneurial employees and top managers agree that work discretion is considered the main dimension that may support intrapreneurial initiatives, whereas the lack of time is not a drawback for intrapreneurship behavior. Giving employees the autonomy to try their own methods of doing their work and reducing the control over their decisions results in more intrapreneurial activities (Sebora et al., 2010). Soluciones Cuatroochenta provides employees with the freedom to use their own judgment, gives them the chance to do something that makes use of their abilities and skills, removes obstacles, and is aware of and very receptive to ideas and suggestions.

Another significant finding is that the most important motivating factor for engaging in intrapreneurial behaviors is the mutual confidence and quality of the relationship in the company. The quality of the relationship between employees and management is a key determinant of loyalty (Leverin and Liljander, 2006), and employees who are loyal to their organizations not only perform better in the workplace but may also motivate others (Hashim et al., 2008). An innovation-focused and supportive management style is a key factor affecting the development of entrepreneurial and innovation behavior 
in organizations (Zhao, 2005). Other aspects, such as interest in discovering "better" ways of doing things, the need to control one's destiny, good work recognition and professional improvement, promotion and the desire to work for oneself, are also relevant drivers of intrapreneurship. Carrier (1996) argues that for small business intrapreneurs reward-related motivations are important and promotion is clearly a significant reward because it is perceived as an excellent opportunity to move closer to the owner-manager, who is generally the main decision-maker. Consequently, intrapreneurs believe that, if promoted, they could take greater initiatives in different areas. Another important reward is ownership of capital stock or any other monetary compensation system, as well as motivations related to past experience and future career objectives.

\section{Theoretical implications}

Previous models of CE mainly focus on organizational and environmental factors as antecedents of the entrepreneurial activity of the firm (e.g. Guth and Ginsberg, 1990; Covin and Slevin, 1991; Lumpkin and Dess, 1996; Antoncic and Hirish, 2001). However, few studies consider the personal factors of intrapreneurs as another antecedent of intrapreneurship (e.g. Powell and Bimmerle, 1980; Hornsby et al., 1993; Ireland et al., 2009). Based on the interactive model of CE (Hornsby et al., 1993), this paper contributes to the understanding of the combination of firm- and individual-level factors that support intrapreneurial behaviors of employees in the context of an NTBF. Our findings suggest that managers should facilitate autonomy/work discretion between employees in order for them to be creative and decide their work methods and what they do in their jobs. Intrapreneurs also recognize top management support for being receptive to new ideas from employees, feedback acknowledging good performance, and help with removing obstacles. These organizational factors together with the mutual confidence and the quality of the relationship between employees and managers, as the main motivational factor, encourage employees' intrapreneurial behaviors for leading projects within an NTBF.

\section{Practical implications}

Our findings provide a number of insights into the influence of an organization's entrepreneurial environment on stimulating the intrapreneurial behaviors of employees that are in line with the results of the latest report on CE in Spain (Ortega et al., 2017). Below, we present the main lessons learnt:

Involvement of the founders and managers of the company in supporting intrapreneurs. Managers can positively influence the entrepreneurial behavior of an organization and improve the perceived confidence of intrapreneurs (Stevenson and Jarillo, 1990; Hornsby et al., 2009). In the case studied, we observe top-down support for employee initiatives. Although not carried out actively or reflected in the procedures and strategies of the company, we observe that intrapreneurship is part of the founders' values that support these initiatives in a reactive way, by providing the structure and resources necessary for these initiatives to emerge within the company. The youth and size of the 
company mean that it is still consolidating its services and timidly opting for projects that are far from its objectives. However, as we have seen, intrapreneurs positively value the ability to communicate their ideas to the CEO and CTO, who are receptive to hearing and valuing them.

Assume that corporate entrepreneurship is a long-term commitment. Project failure in firms involved in CE is frequent and even inevitable (Burgelman and Valikangas, 2005). Companies must therefore assume failure as a natural occurrence and a learning opportunity, and intrapreneurs should not be too worried about the consequences of failure (Altinay, 2005). The intrapreneurial projects that we analyzed are currently growing, but it is still too early to state that they will all be successful.

Provide the organization with skilled people who allow them to accompany and understand startups and intrapreneurs. The organization needs to incorporate people with knowledge and/or skills in entrepreneurship who can adequately value, accompany, and integrate new projects. In this sense, it is imperative that those who are in charge of designing and implementing corporate entrepreneurship programs be familiar with the world of start-ups in order to facilitate understanding between the organization and entrepreneurs. In the case of Soluciones Cuatroochenta, we find that one intrapreneur project (Gamma) is a structure that was created to support mainly external, but also internal, projects.

Look for synergies in the local entrepreneurial ecosystem. There are a large number of agents working for entrepreneurs in the main cities nationwide: venture capital, private investors, public agencies, accelerators, co-working spaces, etc. Knowing what projects entrepreneurs propose and what kind of support they need can be very useful for companies with corporate entrepreneurship programs in order to establish collaborative relationships aimed at detecting entrepreneurial talent by making use of specialized workspaces and inspiration, participating in instruments with external financial institutions, and so forth. Soluciones Cuatroochenta is a central player in the local entrepreneurial ecosystem and collaborates with different local entrepreneurship programs. Among other events, it organizes the Hackathon of Castellón and collaborates with ResetWeekend and other entrepreneurship programs, in collaboration with the Universitat Jaume I and other local players.

Support intrapreneurs with resources, time, and career guarantees. The availability of resources encourages the development of new ideas and projects through experimentation and risk-taking behaviors (Sayles, 1986). It is not reasonable to think that employees can reconcile their daily responsibilities with the implementation of their own project within the organization. For this reason, flexible working conditions, in terms of hours and functions, should be envisaged for intrapreneurs ultimately the total release of the worker from the functions associated with his or her job. In addition, providing employees who participate in intrapreneurship programs with a certain degree of security in the form of a bonus can be a powerful incentive for the development of more intrapreneurial projects. Soluciones Cuatroochenta offers localized support to intrapreneurship projects, flexible schedules, and provides resources to boost the project; however, this support is not widespread. One of the main reasons is the lack of resources or slack resources for these types of objectives. 


\section{Limitations}

The limitations of this work are, first, that it is based on the study of a single case, thereby limiting the generalization of the results on intrapreneurial behaviors in NTBFs. However, some of the results are in line with the recommendations provided by the latest report on CE in Spain (Ortega et al., 2017). Second, we focus on the organizational context and motivations of intrapreneurs as antecedents of the intrapreneurial behavior of employees, but other antecedents could also be analyzed to complement the understanding of intrapreneurial activity. For instance, some authors (e.g. Covin and Slevin, 1991; Antoncic, 2007; Turró et al., 2014) agree that the external environment considerably influences the existence and effectiveness of intrapreneurial behavior. Third, we have approached the intrapreneurial behavior of employees by considering their involvement in the development and leadership of a selfinitiated project. Nonetheless, other authors (e.g. Covin and Slevin, 1989; Rauch et al., 2009) refer to three different dimensions of intrapreneurial behavior such as innovative behavior, personal initiative, and employee risk taking, which may be addressed in future research for a more in-depth analysis of intrapreneurial activity. Recently, Vargas-Halabí et al. (2017) investigated intrapreneurial behavior from the perspective of competencies (opportunity promoter, proactivity, flexibility, drive, and risk taking), which provides another viewpoint to address entrepreneurial behavior. Finally, it would be interesting to replicate the study, based on the same antecedents, in a large firm in order to compare the extent to which the size of the organization may condition the development of intrapreneurial behavior among employees.

\section{Conclusion}

This study analyzed the role of intrapreneurial behaviors of employees in the context of an NTBF, paying attention to the organizational support given to employees' initiatives and the personal motivations of intrapreneurs as antecedents of these behaviors. We found that intrapreneurial projects may arise in firms whose top managers support CE in a non-active manner. Findings on the dimensions of the CEAI that concern intrapreneur behaviors indicate that work discretion may be a supportive factor, whereas the lack of time availability does not prevent intrapreneurship behavior. That intrapreneurs rate mutual confidence and the quality of the relationship between employees and top managers as the most important motivating factor is also noted.

\section{References}

Altinay, L. (2005), "The intrapreneur role of the development directors in an international hotel group", The Service Industries Journal, Vol.25 No.3, pp.403-419.

Antoncic, B. and Hisrich, R.D. (2001), "Intrapreneurship: Construct Refinement and Cross-Cultural Validation”, Journal of Business Venturing, Vol.16 No.5, pp.495-527. 
Antoncic, B. (2007), "Intrapreneurship: a comparative structural equation modelling study", Industrial Management \& Data Systems, Vol.107 No.3, pp.309-25.

Arz, C. (2017), "Mechanisms of organizational culture for fostering corporate entrepreneurship: A systematic review and research agenda", Journal of Enterprising Culture, Vol.25 No.4, pp.361-409.

Bollinger, L., Hope, K. and Utterback, J.M. (1983), "A review of literature and hypotheses on new technology-based firms", Research Policy, Vol.12 No.1, pp.1-14.

Bowen, G. A. (2008), "Naturalistic inquiry and the saturation concept: a research note", Qualitative research, Vol.8 No.1, pp.137-152.

Bruneel, J., Spithoven, A. and Clarysse, B. (2017), "Interorganizational Trust and Technology Complexity: Evidence for New Technology-Based Firms", Journal of Small Business Management, Vol.55 S1, pp.256-274.

Buli, B.M. (2017), "Entrepreneurial orientation, market orientation and performance of SMEs in the manufacturing industry: Evidence from Ethiopian enterprises", Management Research Review, Vol.40 No.3, pp.292-309.

Burgelman, R.A. (1983), “Corporate Entrepreneurship and Strategic Management: Insights from a process study", Management Science, Vol.29 No.12, pp.1349-1364.

Burgelman, R.A. and Valikangas, L. (2005), "Managing internal corporate venturing cycles", MIT Sloan Management Review, Vol.46 No.4, pp.26-34

Burgers, J.H. and Covin, J.G. (2016), "The contingent effects of differentiation and integration on corporate entrepreneurship”, Strategic Management Journal, Vol.37 No.3, pp.521-540.

Carraher, S.M., Hart, D.E., and Carraher Jr, C.E. (2003), "Attitudes towards benefits among entrepreneurial employees", Personnel Review, Vol.32 No.6, pp.683-693.

Carrier, C. (1996), "Intrapreneurship in small businesses: an exploratory study", Entrepreneurship Theory and Practice, Vol.21 No.1, pp.5-20.

Corbett, A., Covin, J.G., O'Connor, G.C. and Tucci, C. L. (2013), “Corporate entrepreneurship: State of the art research and a future research agenda", Journal of Product Innovation Management, Vol.30 No.5, pp.812-820.

Covin, J.G. and Lumpkin, G.T. (2011), "Entrepreneurial orientation theory and research: Reflections on a needed construct" Entrepreneurship Theory and Practice, Vol.35 No.5, pp.855-872.

Covin, J.G. and Slevin, D.P. (1989), "Strategic management of small firms in hostile and benign environments”, Strategic Management Journal, Vol.10 No.1, pp.75-87.

Covin, J. G., and Slevin, D. P. (1991), “A conceptual model of entrepreneurship as firm behavior”, Entrepreneurship theory and practice, Vol.16 No.1, pp.7-26.

Cox, C. and Jennings, R. (1995), "The foundations of success: the development and characteristics of British entrepreneurs and intrapreneurs", Leadership \& Organization Development Journal, Vol.16 No.7, pp.4-9. 
Croonen, E.P., Brand, M.J., and Huizingh, E.K. (2016), "To be entrepreneurial, or not to be entrepreneurial? Explaining differences in franchisee entrepreneurial behavior within a franchise system”, International Entrepreneurship and Management Journal, Vol.12 No.2, pp.531-553.

Dean J.W., Brandes, P. and Dharwadkar, R. (1998), "Organizational cynicism", Academy of Management Review, Vol.23 No.2, pp.341-352.

Dess, G.G., Ireland, R.D., Zahra, S. A., Floyd, S.W., Janney, J.J. and Lane, P.J. (2003), "Emerging issues in corporate entrepreneurship", Journal of Management, Vol.29 No.3, pp.351-378.

De Clercq, D., Castañer, X. and Belausteguigoitia, I. (2011), "Entrepreneurial initiative selling within organizations: Towards a more comprehensive motivational framework", Journal of Management Studies, Vol.48 No.6, pp.1269-1290.

De Villiers-Scheepers, M.J. (2011), "Motivating intrapreneurs: the relevance of rewards", Industry and Higher Education, Vol.25 No.4, pp.249-263.

Eisenhardt, K.M. and Graebner, M.E. (2007), "Theory building from cases: Opportunities and challenges", Academy of Management Journal, Vol.50 No.1, pp.25-32.

Fayolle, A., Kyrö, P. and Ulijn, J. (2005), Entrepreneurship Research in Europe: Outcomes and Perspectives. Edward Elgar Publishing, pp.1-31.

Gerasymenko, V., De Clercq, D. and Sapienza, H.J. (2015), "Changing the business model: effects of venture capital firms and outside CEOs on portfolio company performance", Strategic Entrepreneurship Journal, Vol.9 No.1, pp.79-98.

Grant, A.M. and Ashford, S.J. (2008), "The dynamics of proactivity at work", Research in Organizational Behavior, Vol.28, pp.3-34.

Guth, W. D., and Ginsberg, A. (1990), “Guest editor's introduction: Corporate entrepreneurship", Strategic Management Journal, No.11(special issue), pp.5-16.

Hashim, J., Wok, S. and Ghazali, R. (2008), "Organisational behaviour associated with emotional contagion among direct selling members", Direct Marketing: An International Journal, Vol.2 No.3, pp.144-158.

Hisrich, R.D. and Kearney, C.(2012), Corporate entrepreneurship: How to create a thriving entrepreneurial spirit throughout your company. New York, NY: McGraw-Hill.

Hornsby, J.S., Kuratko, D.F. and Honey, W. (1992), "Emerging growth companies and the at-risk employee: the viability of pre-employment honesty testing", SAM Advanced Management Journal, Vol.57 No.4, pp.24-30.

Hornsby, J. S., Naffziger, D. W., Kuratko, D. F. and Montagno, R. V. (1993), “An interactive model of the corporate entrepreneurship process", Entrepreneurship Theory and Practice, Vol.17 No.2, pp.29-37.

Hornsby, J. S., Kuratko, D. F. and Montagno, R. V. (1999), "Perception of Internal factors for corporate entrepreneurship: A comparison of Canadian and U.S. managers", Entrepreneurship Theory and Practice, Vol.24 No.2, pp. -24. 
Hornsby, J.S., Kuratko, D.F. and Zahra, S.A. (2002), "Middle managers' perception of the internal environment for corporate entrepreneurship: assessing a measurement scale", Journal of Business Venturing, Vol.17 No.3, pp.253-273.

Hornsby, J.S., Kuratko, D.F., Shepherd, D.A. and Bott, J.P.(2009), "Managers' corporate entrepreneurial actions: Examining perception and position", Journal of Business Venturing, Vol.24 No.3, pp.236-247.

Hornsby, J.S., Kuratko, D.F., Holt, D.T., and Wales, W.J. (2013), "Assessing a measurement of organizational preparedness for corporate entrepreneurship", Journal of Product Innovation Management, Vol.30 No.5, pp.937-955.

Hughes, M. and Mustafa, M. (2017), "Antecedents of corporate entrepreneurship in SMEs: Evidence from an emerging economy", Journal of Small Business Management, Vol.55 S1, pp.115-140.

Ireland, R.D., Kuratko, D.F. and Morris, M.H. (2006), "A health audit for corporate entrepreneurship: innovation at all levels: part I", Journal of Business Strategy, Vol.27 No.1, pp.10-17.

Ireland, R. D., Covin, J. G. and Kuratko, D. F. (2009), "Conceptualizing corporate entrepreneurship strategy", Entrepreneurship Theory and Practice, Vol. 33 No.1, 19-46.

Kattenbach, R. and Fietze, S. (2018), "Entrepreneurial orientation and the job demands-resources model", Personnel Review, Vol. 47 No.3, pp.745-764.

Kraus, S., Rigtering, J.C., Hughes, M. and Hosman, V. (2012), "Entrepreneurial orientation and the business performance of SMEs: a quantitative study from the Netherlands" Review of Managerial Science, Vol.6 No.2, pp.161-182.

Kuratko, D. F., Montagno, R. V. and Hornsby, J. S. (1990), "Developing an entrepreneurial assessment instrument for an effective corporate entrepreneurial environment", Strategic Management Journal, Vol.11, pp.49-58.

Kuratko, D.F., Hornsby, J.S., and Bishop, J.W. (2005), “Managers' corporate entrepreneurial actions and job satisfaction", International Entrepreneurship and Management Journal, Vol.1 No.3, pp.275-291.

Kuratko, D.F., Hornsby, J.S. and Covin, J.G. (2014), "Diagnosing a firm's internal environment for corporate entrepreneurship", Business Horizons, Vol.57 No.1, pp.37-47.

Leverin, A. and Liljander, V. (2006), "Does relationship marketing improve customer relationship satisfaction and loyalty?" International Journal of Bank Marketing, Vol.24 No.4, pp.232-251.

Little, A.D. (1977), New technology-based firms in the United Kingdom and the Federal Republic of Germany, London: Wilton House.

Lukes, M. and Stephan, U. (2017), "Measuring employee innovation: a review of existing scales and the development of the innovative behavior and innovation support inventories across cultures", International Journal of Entrepreneurial Behavior \& Research, Vol. 23 No. 1, pp. 136-158.

Lumpkin, G. T., and Dess, G. G. (1996), "Clarifying the entrepreneurial orientation construct and linking it to performance", Academy of Management Review, No.21, pp.135-172. 
Mohanty, R.P. (2006), "Intrapreneurial levers in cultivating value-innovative mental space in Indian corporations", Vikalpa, Vol.31 No.1, pp.99-106.

Monsen, E., and Boss, R.W. (2009), "The impact of strategic entrepreneurship inside the organization: Examining job stress and employee retention", Entrepreneurship Theory and Practice, Vol.33 No.1, pp.71-104.

Monsen, E., Patzelt, H. and Saxton, T. (2010), "Beyond Simple Utility: Incentive Design and TradeOffs for Corporate Employee-Entrepreneurs", Entrepreneurship Theory and Practice, Vol.34 No.1, pp.105-130.

Moriano, J.A., Molero, F., Topa, G. and Mangin, J.P.L. (2014), "The influence of transformational leadership and organizational identification on intrapreneurship", International Entrepreneurship and Management Journal, Vol.10 No.1, pp.103-119.

Moriano, J.A., Topa, G., Valero, E. and Lévy, J.P. (2009), "Identificación organizacional y conducta intraemprendedora", Anales de Psicología/Annals of Psychology, Vol.25 No.2, pp.277-287.

Oldham, G.R. and Cummings, A. (1996), "Employee creativity: Personal and contextual factors at work", Academy of Management Journal, Vol.39, No.3, pp. 607-634.

Ortega Cachón, I., de Pablo López, I., Irujo Salanueva, P. (2017), Emprendimiento Corporativo en España. Elefantes y gacelas bailan sin pisarse, available at: http://cise.es/gem/resumen-ejecutivoinforme-emprendimiento-corporativo.pdf (accessed 10 July 2018).

Pinchot III, G. (1985), Intrapreneuring: Why you don't have to leave the corporation to become an entrepreneur. University of Illinois at Urbana-Champaign's Academy for Entrepreneurial Leadership Historical Research Reference in Entrepreneurship.

Pinchot III, G. (1987), "Innovation through intrapreneuring”, Research Management, Vol.30 No.2, pp.14-19.

Powell, J.D. and Bimmerle, C.F. (1980), "A model of entrepreneurship: moving toward precision and complexity", Journal of Small Business Management, Vol.18 No.1, pp.33-6.

Rauch, A., Wiklund, J., Lumpkin, G.T. and Frese, M. (2009), "Entrepreneurial orientation and business performance: An assessment of past research and suggestions for the future", Entrepreneurship Theory and Practice, Vol.33 No.3, pp.761-787.

Rigtering, J.P.C. and Weitzel, U. (2013), "Work context and employee behaviour as antecedents for intrapreneurship", International Entrepreneurship and Management Journal, Vol.9 No.3, pp.337360.

Saemundsson, R.J. and Candi, M. (2017), “Absorptive capacity and the identification of opportunities in new technology-based firms", Technovation, Vol.64-65, pp.43-49.

Sayles, L.R. (1986), Inside Corporate Innovation: Strategy, Structure, and Managerial Skills. New York: Free Press; London: Collier-Macmillan. 
Sebora, T.C., Theerapatvong, T. and Lee, S.M. (2010), "Corporate entrepreneurship in the face of changing competition a case analysis of six Thai manufacturing firms", Journal of Organizational Change Management, Vol.23 No.4, pp.453-470.

Shearman, C., and Burrell, G. (1988), "New technology based firms and the emergence of new industries: some employment implications", New Technology, Work and Employment, Vol.3 No.2, pp.87-99.

Smith, L., Rees, P. and Murray, N. (2016), “Turning entrepreneurs into intrapreneurs: Thomas Cook, a case-study”, Tourism Management, Vol.56, pp.191-204.

Stevenson, H.H. and Jarillo J.C. (1990), "A Paradigm of Entrepreneurship: Entrepreneurial Management", Strategic Management Journal, Vol.11, pp.17-27.

Storey, D.J. and Tether, B.S. (1998), "New technology-based firms in the European Union: an introduction”, Research Policy, Vol.26 No.9, pp.933-946.

Stull, M. and Singh, J. (2005), "Intrapreneurship in nonprofit organizations examining the factors that facilitate entrepreneurial behaviour among employees", Retrieved May, 24.

Thomas G. (2011), "A typology for the case study in social science following a review of definition, discourse, and structure", Qualitative Inquiry, Vol.17 No.6, pp. 511-521.

Turró, A., Urbano, D., and Peris-Ortiz, M. (2014), "Culture and innovation: The moderating effect of cultural values on corporate entrepreneurship", Technological Forecasting and Social Change, No.88, pp.360-369.

Urban, B. (2017), "Corporate entrepreneurship in South Africa: The role of organizational factors and entrepreneurial alertness in advancing innovativeness", Journal of Developmental Entrepreneurship, Vol.22 No.3, 1-20.

Vargas-Halabí T., Mora-Esquivel R and Siles B. (2017)” Intrapreneurial competencies: development and validation of a measurement scale", European Journal of Management and Business Economics, Vol.26 No.1, pp.86-111.

Wales, W., Monsen, E. and McKelvie, A. (2011), "The organizational pervasiveness of entrepreneurial orientation", Entrepreneurship Theory and Practice, Vol.35 No.5, pp.895-923.

Wang, C.L. (2008), "Entrepreneurial orientation, learning orientation, and firm performance", Entrepreneurship Theory and Practice, Vol.32 No.4, pp.635-657.

Wiklund, J., and Shepherd, D. (2005), "Entrepreneurial orientation and small business performance: a configurational approach", Journal of Business Venturing, Vol.20 No.1, pp.71-91.

Woodman, R.W., Sawyer, J.E. and Griffin, R. W. (1993), "Toward a theory of organizational creativity", Academy of Management Review, Vol. 18, No.2, pp.293-321.

Yin, R.K. (2009), "Case study research: Design and methods" (4th Ed.)., Sage Publication, Thousand Oaks, CA.

Zahra, S.A. and Wright, M. (2011), "Entrepreneurship's next act", Academy of Management Perspectives, Vol.25 No.4, pp.67-83. 
Zellweger, T. and Sieger, P. (2012), "Entrepreneurial orientation in long-lived family firms", Small Business Economics, Vol.38 No.1, pp.67-84.

Zhao, F. (2005), "Exploring the synergy between entrepreneurship and innovation", International Journal of Entrepreneurial Behavior \& Research, Vol.11 No.1, pp.25-41.

Figure 1. CEAI profiles (from founders and employees)

\begin{tabular}{|c|c|c|c|}
\hline & \multicolumn{3}{|c|}{ Level of Dimension } \\
\hline & Low & Medium & High \\
\hline Top management support & & & \\
\hline Work discretion & & & \\
\hline Rewards & & & \\
\hline Time availability & & & \\
\hline Organizational boundaries & & & \\
\hline
\end{tabular}


Table 1. Main features in the intrapreneurial projects studied.

\begin{tabular}{lllllll}
\hline $\begin{array}{c}\text { Project } \\
\text { name }\end{array}$ & $\begin{array}{c}\text { Intrapreneur: } \\
\text { junior/senior } \\
\text { manager or } \\
\text { employee }\end{array}$ & $\begin{array}{c}\text { Intrapreneur's } \\
\text { profile }\end{array}$ & $\begin{array}{c}\text { Importance } \\
\text { of project } \\
\text { for the firm }\end{array}$ & Ideology & Strategic factor & $\begin{array}{c}\text { Result } \\
\text { achieved }\end{array}$ \\
\hline Alpha & Junior employee & Technical profile & Low & $\begin{array}{l}\text { Focused } \\
\text { on growth }\end{array}$ & $\begin{array}{l}\text { New solution: } \\
\text { sharing economy }\end{array}$ & $\begin{array}{l}\text { New } \\
\text { business }\end{array}$ \\
Beta & $\begin{array}{l}\text { Senior } \\
\text { employee }\end{array}$ & $\begin{array}{l}\text { Market } \\
\text { investigation } \\
\text { profile }\end{array}$ & Very High & $\begin{array}{l}\text { Focused } \\
\text { on growth }\end{array}$ & $\begin{array}{l}\text { New solution: } \\
\text { product } \\
\text { innovation }\end{array}$ & New \\
service
\end{tabular}

Source: Adapted from Carrier (1996). 
Table 2. Assessment of dimensions of the CEAI by intrapreneurs and top managers

\begin{tabular}{|c|c|c|}
\hline $\begin{array}{c}\text { CEAI } \\
\text { dimensions }\end{array}$ & $\begin{array}{l}\text { Aspects rated most highly by } \\
\text { intrapreneurs and top managers }\end{array}$ & $\begin{array}{l}\text { Aspects rated the lowest by } \\
\text { intrapreneurs and top managers }\end{array}$ \\
\hline $\begin{array}{l}\text { Top } \\
\text { management } \\
\text { support }\end{array}$ & $\begin{array}{l}\text { My organization is quick to use improved } \\
\text { work methods that are developed by } \\
\text { workers (top managers). } \\
\text { Upper management is aware and very } \\
\text { receptive to ideas and suggestions (top } \\
\text { managers and intrapreneurs). }\end{array}$ & $\begin{array}{l}\text { There are several options within the } \\
\text { organization for individuals to get } \\
\text { financial support for their innovative } \\
\text { projects and ideas (top managers). } \\
\text { Money is often available to get new } \\
\text { project ideas off the ground (top } \\
\text { managers and intrapreneurs). }\end{array}$ \\
\hline \multirow[t]{4}{*}{ Work discretion } & $\begin{array}{l}\text { I feel that I am my own boss and do not } \\
\text { have to double-check all of my decisions } \\
\text { with someone else (top managers). }\end{array}$ & $\begin{array}{l}\text { I seldom have to follow the same work } \\
\text { methods or steps for doing my major } \\
\text { tasks from day to day (top managers). }\end{array}$ \\
\hline & $\begin{array}{l}\text { This organization provides the chance to do } \\
\text { something that makes use of my abilities } \\
\text { (top managers). }\end{array}$ & $\begin{array}{l}\text { The rewards I receive are dependent upon } \\
\text { my innovation on the job } \\
\text { (intrapreneurs). }\end{array}$ \\
\hline & $\begin{array}{l}\text { I almost always get to decide what I do on } \\
\text { my job (intrapreneurs). }\end{array}$ & \\
\hline & $\begin{array}{l}\text { This organization provides the chance to be } \\
\text { creative and try my own methods of doing } \\
\text { the job (intrapreneurs). }\end{array}$ & \\
\hline \multirow[t]{2}{*}{$\begin{array}{l}\text { Rewards and } \\
\text { reinforcement }\end{array}$} & $\begin{array}{l}\text { My supervisor will increase my job } \\
\text { responsibilities if I am performing well in } \\
\text { my job (top managers). }\end{array}$ & $\begin{array}{l}\text { My supervisor will give me special } \\
\text { recognition if my work performance is } \\
\text { especially good (intrapreneurs). }\end{array}$ \\
\hline & $\begin{array}{l}\text { My manager will tell his/her boss if my } \\
\text { work was outstanding (intrapreneurs). }\end{array}$ & \\
\hline \multirow[t]{3}{*}{$\begin{array}{l}\text { Time } \\
\text { availability }\end{array}$} & $\begin{array}{l}\text { My job is structured so that I have very little } \\
\text { time to think about wider organizational } \\
\text { problems (top managers). }\end{array}$ & $\begin{array}{l}\text { I feel that I am always working with time } \\
\text { constraints on my job (top managers). }\end{array}$ \\
\hline & $\begin{array}{l}\text { My co-workers and I always find time for } \\
\text { long-term problem solving } \\
\text { (intrapreneurs). }\end{array}$ & $\begin{array}{l}\text { I always seem to have plenty of time to } \\
\text { get everything done (intrapreneurs). }\end{array}$ \\
\hline & & $\begin{array}{l}\text { My job is structured so that I have very } \\
\text { little time to think about wider } \\
\text { organizational problems } \\
\text { (intrapreneurs). }\end{array}$ \\
\hline $\begin{array}{l}\text { Organizational } \\
\text { boundaries }\end{array}$ & $\begin{array}{l}\text { I clearly know what level of work } \\
\text { performance is expected from me in terms } \\
\text { of amount, quality, and timelines of output } \\
\text { (intrapreneurs). }\end{array}$ & $\begin{array}{l}\text { During the past year, my immediate } \\
\text { supervisor discussed my work } \\
\text { (intrapreneurs). }\end{array}$ \\
\hline
\end{tabular}


Table 3. The personal motivators of intrapreneurs

\begin{tabular}{|c|c|c|}
\hline $\begin{array}{l}\text { Motivations of } \\
\text { intrapreneurs }\end{array}$ & The most motivating factors & The least motivating factors \\
\hline \multirow[t]{2}{*}{$\begin{array}{l}\text { Intrinsic personality } \\
\text { related motivations }\end{array}$} & $\begin{array}{l}\text { Interest in discovering "better" } \\
\text { ways of doing things }\end{array}$ & $\begin{array}{l}\text { Intrapreneurial personality eager } \\
\text { for challenge and achievement }\end{array}$ \\
\hline & - A need to control one's destiny & $\begin{array}{l}\text { A sense of working for oneself } \\
\text { foremost }\end{array}$ \\
\hline \multirow[t]{2}{*}{$\begin{array}{l}\text { Extrinsic reward } \\
\text { related motivations }\end{array}$} & $\begin{array}{l}\text { Good work recognition and } \\
\text { professional improvement }\end{array}$ & Access to capital stock \\
\hline & . Promotion & Innovation bonuses \\
\hline $\begin{array}{l}\text { Motivations related } \\
\text { to past experience } \\
\text { and future career } \\
\text { objectives }\end{array}$ & . Desire to work for oneself & $\begin{array}{l}\text { "Plateaued" (in the restrictive } \\
\text { sense) in a previous job }\end{array}$ \\
\hline $\begin{array}{l}\text { Motivations related } \\
\text { to the organizational } \\
\text { context }\end{array}$ & $\begin{array}{l}\text { Mutual confidence and quality } \\
\text { of the relationship }\end{array}$ & $\begin{array}{l}\text { Shared vision with the } \\
\text { entrepreneur }\end{array}$ \\
\hline
\end{tabular}

